Ulusal Bağışıklama Programına Girmeden

\title{
Administration Frequencies of Hepatitis A and Hepatitis B Vaccines at Two Schools with Different Socioeconomic Status Before Admission to National Immunization Program
}

Öz

Amaç: Hepatit A ve hepatit B aşılarının ülkemiz Genişletilmiş Bağışıklama Programı'na girmeden önce, sosyoekonomik düzeyleri farklı iki okulda, 7-15 yaş arası çocuklarda her iki etkene yönelik aşılama oranlarının ve seroprevelansların karşılaştırılması amaçlanmıştır. Yöntem: Çalışmamız, 2003 yılında, İstanbul Bakırköy ilçesinde, sosyoekonomik düzeyi farklı iki okulda öğrenim gören 546 çocuk arasında yapılmıştır. Ebeveynlere çalışma öncesi bilgilendirme toplantısı yapılmış, çalışmaya gönüllü ebeveynlerin çocukları çalışmaya dâhil edilmiştir. Çocukların hepatit $A$ ve hepatit $B$ aşıları uygulanma durumu, çocukta sarılık geçirme öyküsü sorgulandı. Çocuklardan alınan venöz kanlardan Anti HAV IgG, HbsAg, Anti Hbs belirteçleri çalışııımıştır.

Bulgular: Sosyoekonomik düzeyin daha yüksek olduğu okulda hepatit A ve hepatit B aşısı ile aşılanma oranları ve bu etkenlerin seroprevalansları istatistiksel anlamlı olarak yüksek saptanmıştır.

Sonuç: Ulusal Aşılama Programı́nda yer almayan aşıların uygulanması, sosyoekonomik düzeye göre farklılık gösterebilmektedir. Günümüzde hepatit $A$ ve hepatit B aşılarının Ulusal Bağışıklama Programı́nda yer alması, çocuk sağlığında var olan bir sosyal eşitsizliğin kaldırılması açısından önemli bir halk sağlığı girişimidir.

Anahtar kelimeler: Hepatit A, hepatit B, ulusal bağışılama programı, sosyoekonomik düzey, çocuklar

\section{ABSTRACT}

Objective: The aim of this study was to compare the vaccination rates and seroprevalences related to hepatitis $A$ and hepatitis $B$ vaccines in children between 7-15 years of age, in two schools from different socioeconomic levels, before they entered in The Expanded Programme on Immunization in Turkey.

Method: Our study was performed in 2003 in 546 children in two schools from different socioeconomic status in Istanbul Bakırköy district. Parents were informed before the study in an informative meeting and children of those parents who were willing to participate in the study were included in this survey. Administration of hepatitis $A$ and $B$ vaccines and history of jaundice in children were questioned. Anti HAV IgG, HbsAg and Anti Hbs markers were studied from venous blood samples drawn from children

Results: Vaccination rates with hepatitis $A$ and hepatitis $B$ vaccines and seroprevalence of these agents were found to be significantly higher in the school where the socioeconomic level was higher.

Conclusion: The administration of vaccines not included in National Immunization Program may vary depending on socioeconomic status. Today, the implementation of hepatitis $A$ and hepatitis $B$ vaccines into The National Immunization Program is an important public health initiative in terms of removing the existing social inequality in child health.

Keywords: Hepatitis $A$, hepatitis $B$, national immunization program in Turkey, socioeconomic status, children 
B. Kural, Ulusal Bağışıklama Programına Girmeden Önce Farklı Sosyoekonomik Düzeyleri Bulunan İki Okulda Hepatit A ve Hepatit B Aşılarının Uygulanma Sıklıkları

\section{GíRiş}

Aşılamanın halk sağlığı müdahalelerinin en uygun maliyetlisi olduğu yıllar içinde kanıtlanmıştır. Dünya Sağlık Örgütü’nün "sağıı”” tanımlaması içinde, ulaşılabilir en yüksek sağlık standardından yararlanma, ırk, din, politik inanç, ekonomik veya sosyal durum ayrımı yapmaksızın her insanın temel haklarından biri olduğu vurgulanmıştır. 2017'de aşılanan çocuk sayısı dünyada 116.2 milyon olarak bildirilmiş, şimdiye kadar ulaşılabilen en yüksek rakam olduğu belirtilmiştir. Aşılama ile yaklaşık yılda 2,5 milyon beş yaş altı çocuk ölümü önlenmektedir ${ }^{(1-3)}$. Başarılı aşılama programı ile çiçek hastalığı dünyada eradike edilmiş, en son vaka 1977 'de Somali'den bildirilmiştir ${ }^{(4)}$. Ülkemizde son polio vakası 1998 'de görülmüş, Türkiye 2002 yılında poliodan arındırılmış bölge sertifikası almıştır ${ }^{(5)}$. Dünyada poliovirüs, $2018^{\prime}$ de üç bölgede halen dolaşımdadır ${ }^{(1)}$.

Hepatit A ve hepatit B aşı ile önlenebilir hastalıklardandır. Ülkemizde doğan çocuklara Haziran 1998'den itibaren hepatit B aşısı ve Ekim 2012'den itibaren hepatit A aşısı "Genişletilmiş Bağışıklama Programı" dâhilinde ücretsiz uygulanmaya başlanmıştır. 20052009'da ilk ve ortaöğretimde hepatit B aşılaması yapılmıştır ${ }^{(5,6)}$. Hepatit $B$ aşısı 2017 verilerine göre dünyada 188 ülkede rutin olarak uygulanmaktadır ${ }^{(7)}$. Dünya Sağlık Örgütü, ülkede hepatit A'nın görülme sıklığına, endemisitesinin yüksek ve orta derecede olmasına ve aşının maliyet etkinliğine dayanarak hepatit A aşısının çocukluk çağı ulusal aşılama programına dâhil edilmesini önermektedir ${ }^{(8)}$. Ülkemiz hepatit $\mathrm{A}$ aşısını ulusal aşılama takvimine alan dünya ülkeleri sıralamasında 12.'dir ${ }^{(5)}$.

Aşı kapsama oranları ülkeler ve bölgeler arasında büyük ölçüde değişmeye devam etmektedir. Bunun sonucu olarak, 2017 yılında yaklaşık 20 milyon çocuk yeterince aşılanamamışırı. Sosyoekonomik durumla ilgili aşı kapsamında, ulusal farklılıklar hakkında yeni veriler bulunmamakta, bu konu ele alınması gereken önemli bir boşluk olmaya devam etmektedir ${ }^{(1)}$. Tüm zorunlu ve önerilen aşıların \% 100'ünün hem kamu kurumlarında hem de özel uygulamalarda ücretsiz sağlanması ile aşılama programlarının geliştirilebileceği düşünülmektedir ${ }^{(9)}$.

Çalışmamız 2003 yılında, Sağlık Bakanlığı tarafından hepatit $A$ ve hepatit $B$ aşılarının aşılama programında rutin olarak uygulanmadığı 7-15 yaş grubuna, piyasada var olan aşıların ailelerin istekleri doğrultusunda çocuklarına yaptırdığı veya seropozitivitenin hastalığın geçirilmesi ile kazanıldığı dönemde yapılmıştır. Aynı çevrede yer alan, sosyoekonomik düzeyi farklı iki okulda hepatit A ve hepatit $B$ aşılanma oranlarını ve seroprevalanslarını karşılaştırmak amacıyla yapılmıştır.

\section{GEREÇ ve YÖNTEM}

Bu kesitsel çalışma, İstanbul Bakırköy ilçesi Milli Eğitim Müdürlüğüne bağı iki ilköğretim okuluna devam eden öğrenciler arasında yapılmıştır. Okul 1, Bakırköy bölgesi düşük-orta sosyoekonomik düzeydeki öğrencilerin, okul 2 ise yıllık ücreti yaklaşık 7.500 USD (Amerikan doları) olan yüksek sosyoekonomik düzeydeki öğrencilerin devam ettiği okullardır. Taramaları yapabilmek için il Milli Eğitim Müdürlüğünden ve İ Sağlık Müdürlüğünden yazılı izinler ve etik kurul onayı alınmıştır. Her iki okulda ebeveynlere çalışmanın amacını ve hepatit $A$ ve $B$ enfeksiyonlarını anlatan "çalışma öncesi sunumlar" gerçekleştirilmiştir. Bu sunumlar standart olarak yapılandırımıştır. Taramayı kabul etmeyen ebeveynlerin çocukları çalışmaya dâhil edilmemiştir. Çalışmaya katılan çocukların ebeveynlerinden yazılı onam alınmıştır. Anne-babalara çocuğuna hepatit A ve hepatit B aşıları uygulanmasını, çocukta sarılık hastalığı öyküsünü sorgulayan anketler yanıtlandırılmıştır. Aşıların uygulandığından emin olmayan ailelerin çocuklarının aşı karneleri değerlendirilmiştir. Çocuklardan aseptik koşullarda, venöz kan örnekleri alınmıştır. Sonuçlar ailelere kapalı zarflar ile gönderilmiştir. Sonuçları aileler ile paylaşmak ve sorularını yanıtlamak üzere "çalışma sonu toplantıları" düzenlenmiştir.

Serolojik çalışma, İstanbul Üniversitesi İstanbul Tıp 
Fakültesi Klinik Mikrobiyoloji Anabilim Dalı, Viroloji ve Temel İmmunoloji Bilim Dalı Laboratuarında, BioRat Anti-HAV Ig G (Pasteur ${ }^{\circledR}$ ), BioRat $\mathrm{HBs} \mathrm{Ag}$ (Pasteur ${ }^{\circledR}$ ), BioRat Anti-HBs (Pasteur ${ }^{\circledR}$ ) kitleri kullanılarak yapılmıştır. Serolojik sonuçlar ve anketlerden elde edilen verilerin istatistiksel analizi, İstanbul Üniversitesi Cerrahpaşa Tıp Fakültesi Biyoistatistik Kürsünde değerlendirildi. Ki-kare $\left(\chi^{2}\right)$ ve Fisher's Exact analiz testleri kullanılmıştır.

\section{BULGULAR}

Okul 1'de 7-15 yaş arası 284 öğrenci, okul 2'de 7-15 yaş arası 262 öğrenci çalışmaya alınmıştır (Tablo 1). íki okul arasında çalışmaya katılan çocuklarda, cinsiyet açısından fark yoktur $(\mathrm{p}=0.611)$. Okul $1^{\prime}$ in yaş ortalaması $10.7 \pm 2.2$ yaş iken, okul 2 'nin yaş ortalaması $9.8 \pm 2.4$ yaş olarak bulunmuştur. Her iki okulda, ebeveynlerinin söylemlerine göre geçirilmiş sarılık öyküsü olan çocuk yoktur.

Tablo 1. Okullarda cinsiyete göre vakaların dağılımı.

\begin{tabular}{lccc}
\hline & Okul $\mathbf{1}$ & Okul 2 & Toplam \\
\hline Kız & 159 & 141 & 300 \\
Erkek & 125 & 121 & 246 \\
\hline Toplam & 284 & 262 & 546 \\
\hline
\end{tabular}

íki okul arasında Anti-HAV Ig G ve Anti-HBs seropozitivitesinde anlamlı fark saptanmıştır $(p<0.05)$. HBs Ag pozitifliği yalnızca okul 1'de, bir öğrencide belirlenmiştir. Okullardaki seropozitivite oranları Tablo 2'de belirtilmiştir. Tüm grupta anti-HAV IgG, $\mathrm{Hbs} \mathrm{Ag}$ ve Anti Hbs Ag prevalansı sırasıyla; \% 23.4, \% 0.2, \% 44.8 bulunmuştur. İki okul arasında Anti-HAV IgG ve AntiHBs seropozitivitesinde anlamlı fark saptanmıştır $(p<0.001)$.

Tablo 2. Okullardaki seropozitivite oranları.

\begin{tabular}{cccc}
\hline & $\begin{array}{c}\text { AntiHAV IgG } \\
\text { pozitifliği } \\
\%(n)\end{array}$ & $\begin{array}{c}\text { HbsAg } \\
\text { pozitifliği } \\
\%(n)\end{array}$ & $\begin{array}{c}\text { AntiHbs } \\
\text { pozitifliği } \\
\%(n)\end{array}$ \\
\hline Okul 1 & $11.3(32 / 284)$ & $0.4(1 / 284)$ & $26.8(76 / 284)$ \\
Okul 2 & $36.6(96 / 262)$ & 0 & $64.5(169 / 262)$ \\
\hline
\end{tabular}

Hepatit A ve hepatit B aşılarının uygulanmasında iki okul arasında anlamlı fark mevcuttur $(p<0.001)$. Sosyoekonomik düzeyi yüksek olan okulda her iki aşının da uygulanma sıklığı daha yüksektir (Tablo 3).

Tablo 3. Okullardaki aşılanma oranları.

Hepatit A aşılanması \% (n) Hepatit B aşılanması \% (n)

Okul $1 \quad 1.8(5 / 284) \quad 15.8(45 / 284)$

Okul $29.8(78 / 262) \quad 63.4(166 / 262)$

\section{TARTIŞMA}

Çalışmamız, 2003 yılında, hepatit A ve hepatit B aşılarının Genişletilmiş Bağışıklama Programı dâhilinde uygulanmadığı dönemde yapılmıştır. İstanbul'da aynı ilçede bulunan, sosyoekonomik düzeyi farklı iki ilköğretim okulunda, 7-15 yaş grubundaki çocuklarda hepatit $A$ ve $B$ aşılarının uygulanma sıklığı ve etkenlere karşı oluşan seropozitivite sosyoekonomik düzeyi yüksek okulda, istatistiksel olarak anlamlı yüksek bulunmuştur.

Sosyoekonomik düzeyi yüksek okulda hepatit $A$ ve B aşısı ile aşılanma oranları sırasıyla \%29.8 ve \%63.4 iken; sosyoekonomik düzeyi düşük olan okulda bu oranlar \%1.8 ve \%15.8 olarak belirlenmiştir. Hepatit $A$ ve hepatit $B$ aşılarının Sağıı Bakanlığı tarafından ücretsiz olarak uygulanmaya başlamasından sonra 2002'de hepatit B aşısı uygulanma sıklığı \%72 iken, 2015'te sıklık \%97, 2017'de \%99'a ulaşmıştır. Hepatit A aşısı uygulanma sıkığı 2013-2017 yılları arasında $\% 91$ olarak belirtilmiştir ${ }^{(5,10)}$.

Düşük gelir düzeyi, ebeveyn eğitimi eksikliği, sağlık tesislerine erişimin yetersizliği ve geleneksel inançlar dâhil olmak üzere aşıya ulaşmanın önünde birçok engel vardır. Düşük ve orta gelirli ülkelerdeki 18-29 ay arası çocuklarda tam aşıı olma kapsamındaki eşitsizlikleri araştıran çalışmada Türkiye'den 2003 verileri kullanılmıştır. Servet dağıımını hesaplamada kullanılan eşitsizlik eğim indeksleri açısından Nijerya, tam bağışıklama kapsamındaki en büyük zengin yanlısı 
B. Kural, Ulusal Bağışıklama Programına Girmeden Önce Farklı Sosyoekonomik Düzeyleri Bulunan İki Okulda Hepatit A ve Hepatit B Aşılarının Uygulanma Sıklıkları

eşitsizliği göstermiş, bunu Pakistan, Hindistan, Türkiye, Madagaskar, Yemen, Kamerun ve Liberya takip etmiştir. Türkiye, tam aşılı olmada kent yanlısı fark göstermiştir (11). Türkiye Nüfus ve Sağlık Araştırmaları (TNSA) 2013 verilerinde, kentsel alanlarda ikinci ve üçüncü doz Hepatit B ve KPA aşılarını olan çocukların oranı kırsal alanlardaki çocuklara göre daha yüksektir. Bölgesel farklılıklar ele alındığında, tam aşılı çocukların yüzdesi doğuda en düşük; güney ve orta bölgelerde ise en yüksektir ${ }^{(12)}$. Çalışmamız, İstanbul'da aynı ilçede yer alan iki okulda yapılmış, aşılama açısından sağlık tesislerine erişim, kentsel-kırsal farkııı̆ının olmadığı bir konum seçilmiştir.

Ulusal zenginlik aşı kapsama ile bağışıklık sistemi performansını etkileyebilmektedir ${ }^{(1)} .2000$ yılında kurulan Küresel Aşı İttifakı (Global Alliance for Vaccines and Immnuzation-GAVI) dünyanın en yoksul ülkelerinde yaşayan çocuklar için yeni ve ulaşımı kısıtlı aşılara eşit erişim sağlama hedefiyle kamu ve özel sektörleri bir araya getirmektedir (13). GAVI önceliğinde çocukluk çağında aşılama kapsama analizinde, aşılamadaki eşitsizliklerle ilgili çeşitli faktörler tanımlanmıştır. Annenin eğitim düzeyinin, annenin doğumdaki yaşının ve kaçıncı doğumu olduğunun, hanehalkı ekonomik durumunun aşılanma olasılığı üzerinde önemli bir etkisi olmuştur. Çocuğun cinsiyetinde aşılama açısından farklılık gözükmemektedir ${ }^{(1)}$. GAVI desteği alan 45 ülkede yapılan bir çalışmada, politik istikrar ve şiddetin yokluğunun ülkelerde aşı kapsama eşitsizlikleri ile ters orantılı bulunmuştur. Sağlıkta daha fazla devlet harcaması ve daha az dilsel fraksiyonalizasyon ile daha iyi aşılama sonuçları gözlenmiştir ${ }^{(14)}$. Dünyada Ekonomik İşbirliği ve Kalkınma Örgütü (OECD) üyesi ülkelerle karşılaştırıldığında, Meksika ve Şili'den sonra, Türkiye eşitlikçi olmayan gelir dağılımına sahip ülkelerdendir ${ }^{(15)}$. Gelir dağılımı farklılıkları, sosyoekonomik farklılıkları da oluşturabilmektedir. TNSA 2013 verisinde aşılanma oranı hanehalkı refah düzeyi ile hızlı bir şekilde artmaktadır. En düşük refah düzeyindeki çocukların \%63'ü tam aşılıyken, bu oran en yüksek refah gruplarında \% 79'dur ${ }^{(12)}$.
Çocuğun aşılanma durumuyla annenin eğitim düzeyi arasında yakın bir ilişki vardır. TNSA 2013 verilerinde, hiç eğitimi olmayan veya ilkokulu bitirmemiş annelerin çocuklarında tam aşılılık \% 63 iken, en az lise eğitimi alan annelerin çocuklarında bu oran \% 78'e yükselmektedir ${ }^{(12)}$. Zorunlu eğitim kapsamında annenin eğitim yılı arttıkça ülkemizde hepatit B ve difteritetanoz-boğmaca aşılarının tamamlanma olasılığının arttığı belirtilmiştir ${ }^{(16)}$. Çalışmamızda, ebeveynlerin eğitim durumları araştırılmamıştır, bu durum çalışmamızın kısıtılıklarından sayılabilir. Çalışma öncesi ebeveynlere verilen standart bilgilendirme sonrasında, çalışmaya katılmaya gönüllü olan ebeveynlerin bağışıklamaya karşı benzer tutumları olduğu öngörülmüştür.

Sonuç olarak, ülkemizde farklı sosyoekonomik düzeylerde yaşayan çocukların hepatit $B$ ve hepatit $A$ aşılarının Ulusal Aşı Programı’na alınması, çocuk sağlığında var olan bir sosyal eşitsizliğin kaldırılması açısından önemli bir halk sağlığı girişimidir.

Teşekkür: Çalışmadaki desteğinden dolayı Doç. Dr. Sadık Sami Hatipoğlu'na teşekkür ederiz.

Etik Kurul Onayı: İl Milli Eğitim Müdürlüğünden ve îl Sağlık Müdürlüğünden yazılı izinler ve Etik Kurul onayı alınmıştır.

Hasta Onayı: Çalışmaya katılan çocukların ebeveynlerinden yazılı onam alınmıştır.

Ethics Committee Approval: Written permissions and ethics committee approval were obtained from Provincial Directorate of National Education and Provincial Directorate of Health.

Informed Consent: Written consent was obtained from the parents of the children who participated in the study.

\section{KAYNAKLAR}

1. Dünya Sağlık Örgütü (2018). 2018 Assessment report of the Global Vaccine Action Plan. Strategic Advisory Group of Experts on Immunization. Geneva: World Health Organization; 2018. https://www.who.int/ 
immunization/global_vaccine_action_plan/SAGE_ GVAP_Assessment_Report_2018_EN.pdf(Son erişim tarihi: 12/04/2019)

2. Dünya Bankası (1993). World Development Report 1993: investing in health. Washington DC: World Bank;1993. https://openknowledge.worldbank.org/ handle/10986/5976 (Son erişim tarihi: 12/04/2019)

3. Dünya Sağlık Örgütü (1946). Constitution of the World Health Organization, Geneva, Switzerland: World Health Organization. www.who.int/governance/en/. (Son erişim tarihi: 12/04/2019)

4. Dünya Sağlık Örgütü (2010). Scientific review of variola virus research, 1999-2010. Geneva, Switzerland: World Health Organization; 2010. https://apps.who.int/iris/ bitstream/handle/10665/70508/WHO_HSE_GAR_ BDP_2010.3_eng.pdf;jsessionid=248DBDD048233A36 A55A9435CE087F76?sequence=1 (Son erişim tarihi: 12/04/2019)

5. Topaç O. Bağışıklamada Güncel Durum. 4.Ulusal Pediatri Kongresi 16-19 Kasım 2016,Antalya 2016. http://www.sosyalpediatri.org.tr/uploads/ osmantopac.pdf (Son erişim tarihi: 12/04/2019)

6. Badur S. Türkiye ve Dünyada HBV Proflaksisi. In: Çakaloğlu Y, Ökten A. eds. Hepatit B Uzlaşma Metinleri. 2. Baskı. İstanbul: İstanbul Medikal Yayıncılık, 2004:147-164.

7. Dünya Sağlık Örgütü (2017). 2017 Assessment Report of the Global Vaccine Action Plan Strategic Advisory Group of Experts on Immunization. Geneva: World Health Organization; 2017. https://www.who.int/ immunization/global_vaccine_action_plan/sage_gvap_ october_2017/en/ (Son erişim tarihi: 12/04/2019)

8. Dünya Sağlık Örgütü (2016). Technical considerations and case definitions to improve surveillance for viral hepatitis: technical report. Geneva, Switzerland: World Health Organization; 2016. https://apps.who.int/iris/ bitstream/handle/10665/204501/9789241549547_ eng.pdf?sequence $=1$ (Son erişim tarihi: $12 / 04 / 2019$ )

9. Bocquier A, Ward J, Raude J, Peretti-Watel P, Verger P. Socioeconomic differences in childhood vaccination in developed countries: a systematic review of quantitative studies. Expert Rev Vaccines. 2017;16(11):1107-18.

https://doi.org/10.1080/14760584.2017.1381020

10. Dünya Sağlık Örgütü (2017). WHO/UNICEF estimates of national immunization coverage. Turkey: WHO and UNICEF estimates of immunization coverage: 2017 revision. Hepatitis B.p:11. https://www.who.int/ immunization/monitoring_surveillance/data/tur.pdf (Son erişim tarihi: 12/04/2019)

11. Restrepo-Méndez MC, Barros AJ, Wong KL, Johnson $\mathrm{HL}$, Pariyo G, França GV, et al. Inequalities in full immunization coverage: trends in low- and middleincome countries. Bull World Health Organ. 2016;94(11):794-805B. https://doi.org/10.2471/BLT.15.162172

12. Hacettepe Üniversitesi Nüfus Etütleri Enstitüsü. "2013 Türkiye Nüfus ve Sağlık Araştırması (TNSA)". Hacettepe Üniversitesi Nüfus Etütleri Enstitüsü, T.C. Kalkınma Bakanlığı ve TÜBiTAK, Ankara, Türkiye.

13. Global Alliance for Vaccines and Immunizations (GAVI). About Gavi, the Vaccine Alliance. https://www.gavi. org/about/ (Son erişim tarihi: 12/04/2019)

14. Arsenault C, Johri M, Nandi A, Rodrigues JMM, Hansen PM, Harper S. Country-level predictors of vaccination coverage and inequalities in Gavi-supported countries. Vaccine 2017;35:2479-88.

https://doi.org/10.1016/j.vaccine.2017.03.029

15. Birleşmiş Milletler Kalkınma Programı (2016). Buğra $A$, Yılmaz V, Birelma A, Gürsoy B, Taşkın Y, Dodurka ZB, et.a. Inequalities in Turkey: An Overview Final report. Regional Human Development Report 2016. http:// www.tr.undp.org/content/turkey/en/home/library/ human_development/socialinequalities.html (Son erişim tarihi: 12/04/2019)

16. Özer M, Fidrmuc J, Eryurt MA. Maternal education and childhood immunization in Turkey. Health Econ, 2018;27(8):1218-29.

https://doi.org/10.1002/hec.3770 